\title{
In Situ Localization and Characterization of Active Proteases in Chronically Inflamed and Healthy Human Gingival Tissues
}

David P. Sarment, * Jonathan Korostoff, ${ }^{\dagger}$ Marina D’Angelo, ${ }^{\ddagger}$ Alan M. Polson, $§$ Roy S. Feldman, $\S \|$ and Paul C. Billings ${ }^{\ddagger}$

Background: Studies have indicated an important role for host-derived proteases in the pathogenesis of periodontal disease. The objectives of this study were: 1) to develop an assay measuring protease activity in situ and 2) to localize and characterize the enzymatic activity in intact inflamed and healthy gingiva.

Methods: Gingival specimens were prepared and overlaid with a quenched fluorescent substrate. Protease activity was visualized by fluorescence microscopy and correlated with histologic features.

Results: In inflamed tissues, enzymatic activity was detected mainly in the connective tissue (predominantly matrix metalloproteases) and, to some extent, in the epithelium (predominantly serine proteases). In contrast, clinically healthy tissues failed to exhibit significant amounts of protease activity. Quantitative and qualitative characteristics of protease activity in intact tissues were found to be $\mathrm{pH}$ dependent.

Conclusions: The method described here enabled assessment of active proteases in intact tissues where cell-cell and cell-matrix interactions had been maintained. Our results indicate that there are substantial differences in the distribution of specific proteases between clinically healthy and inflamed periodontal tissues. J Periodontol 1999;70:1303-1312.

\section{KEYWORDS}

Gingiva/enzymology; inflammation; periodontal diseases/diagnosis; proteases/analysis; spectroscopy, fluorescence; matrix metalloproteases; serine proteases.

\footnotetext{
* Previously, Department of Periodontics and Department of Anatomy and Histology, School of Dental Medicine, University of Pennsylvania, Philadelphia, PA and Veterans Affairs Medical Center, Philadelphia; currently, Department of

Periodontics/Prevention/Geriatrics, University of Michigan School of Dentistry, Ann Arbor, MI.

$\dagger$ Department of Microbiology, School of Dental Medicine, University of

Pennsylvania.

* Department of Anatomy and Histology.

$\S$ Department of Periodontics.

$\|$ Veterans Affairs Medical Center, Philadelphia, PA.
}

$\mathrm{H}$ ost-derived proteases are currently believed to play a key role in the tissue destruction associated with many inflammatory processes, including rheumatoid arthritis and the various forms of periodontal disease. ${ }^{1,2}$ An initiating event in the progression of chronic periodontal disease is the host immune reaction to bacterial colonization of the gingival sulcus, resulting in the recruitment of inflammatory cells, i.e., neutrophils, macrophages, and lymphocytes, to the site of infection. ${ }^{3}$ In response to bacterial products and/or host factors, these cells release proteases which, in turn, participate in the degradation of the extracellular matrix (ECM) of the periodontium. ${ }^{2}$

Early studies demonstrated the presence of collagenolytic activity in diseased gingival explants. ${ }^{4,5}$ Additional investigations delineated the properties of these collagenases and indicated that the enzymes could be released from both resident connective tissue and epithelial cells, as well as infiltrating inflammatory cells. ${ }^{6}$ More recent studies have attempted to correlate the levels of protease activity with periodontal disease severity. ${ }^{7-10}$ In general, increased levels of proteolytic activity were detected within gingival crevicular fluid and extracts prepared from inflamed gingival tissues, when compared to healthy control samples.

It is currently recognized that members of the matrix metalloprotease (MMP) family of ECMdegrading neutral endopeptidases account for much of the proteolytic activity measured in sites of gingival inflammation. Specifically, these include the gelatinases (MMPs-2 and -9), ${ }^{9}$ stromelysin (MMP-3), ${ }^{1,9}$ and the collagenases (MMPs-1, -8, and -13). ${ }^{10,11}$ These overall observations suggest that activated MMPs are major 


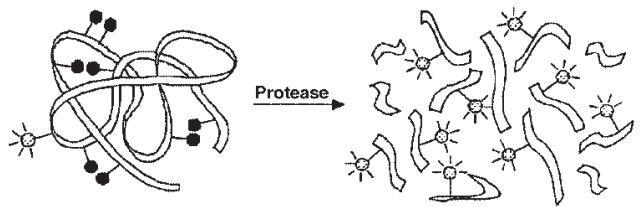

Figure $I$.

Protease-catalyzed hydrolysis relieves the fluorescence-quenching of BODIPY TR-X labeled B-casein. As illustrated in the schematic, the fluorescence of the native molecule is quenched due to the molecular configuration of the molecule. Following proteolytic cleavage, the quenching is relieved and the magnitude of resultant fluorescence is proportional to the extent of proteolytic digestion.

participants in the destruction of connective tissues, which is a hallmark of periodontitis.

In situ, protease activity is regulated in a hierarchical fashion: ${ }^{1}$ 1) at the transcriptional level where protease gene expression can be altered in response to specific inflammatory mediators and cytokines; ${ }^{12}$ 2) at the translational level where proteases are synthesized as latent forms requiring processing for conversion into their active proforms; ${ }^{13} 3$ ) by sequestration in secretory vesicles such as the azurophilic granules in neutrophils; ${ }^{14}$ and 4) by the presence of endogenous inhibitors such as the tissue inhibitors of metalloproteinases (TIMPs). ${ }^{15,16}$ The regulatory mechanisms within intact tissues have made it difficult to identify activated proteases using conventional biochemical techniques. ${ }^{17}$ Furthermore, the alternative approach of in situ immunohistochemistry does not discern between latent and active forms, nor does it reflect the presence of endogenous protease inhibitors. Therefore, the goal of the current study was to develop a technique which would identify and localize activated proteases within intact healthy and diseased periodontal tissues. Our results demonstrate the presence of activated MMPs and serine proteases in inflamed gingiva, and indicate that these enzymes are differentially distributed between the connective tissue and epithelial compartments of the periodontium.

\section{MATERIALS AND METHODS}

\section{Tissue Specimens}

Gingival tissue samples were obtained from patients attending the dental clinics within the University of Pennsylvania (Graduate Periodontics Clinic at the School of Dental Medicine and the Department of Oral and Maxillofacial Surgery of the University of Pennsylvania Medical Center) and Dental Service, Veterans Affairs Medical Center (Philadelphia). Twelve patients participated in the study: 6 patients in the diseased group ranging in age from 26 to 52 years (average $36.3 \pm 9.8 \mathrm{SD}$ ); and 6 in the control group (i.e., clinically healthy tissues) with ages ranging from 36 to 52 years (average $44.7 \pm 7.8$ SD). The protocol was approved by the Institutional Review Board of the University of Pennsylvania.

All patients participating in the study were physically healthy and none had received prescribed antibiotics or anti-inflammatory medications in the 6 months prior to their periodontal surgery. Patients were diagnosed with chronic adult periodontal disease based on visual signs of inflammation, ${ }^{18}$ probing depths $\geq 5 \mathrm{~mm}$, and bleeding upon probing at the base of the pockets. ${ }^{19,20}$ Tissues removed at surgical pocket elimination comprised the clinically inflamed specimens. Non-inflamed specimens (absence of visual signs of inflammation, probing depth $\leq 3 \mathrm{~mm}$, and absence of bleeding upon probing at the base of the pocket) were obtained from patients undergoing crown lengthening procedures.

\section{Tissue Protease Activity and Histologic Mapping}

Tissue specimens for in situ zymography were oriented, using a horizontal reference incision made prior to tissue removal, to allow visualization of pocket and oral epithelium within the same section. ${ }^{21,22}$ Samples were embedded in tissue freezing medium without fixation, and stored at $-80^{\circ} \mathrm{C}$. For analysis, $6 \mu \mathrm{m} \mathrm{sec}-$ tions were cut at $-16^{\circ} \mathrm{C}$ and immediately overlaid with the substrate BODIPY TR-X labeled $\beta$-casein 9 (4 mg/ml in $10 \mathrm{mM}$ Tris, pH 6, 7, or 7.8), coverslipped, and incubated in a dark humidified chamber at $37^{\circ} \mathrm{C}$ for 3 hours. This assay is based on the principle that substrate fluorescence is quenched in its native form and, upon cleavage by proteases, the quenched substrate becomes fluorescent (Fig. 1). ${ }^{23}$ Areas of proteolytic activity are readily visible as discrete regions of fluorescence.

Sections were photographed at 400x magnification and digitized with a slide scanner. ${ }^{\#}$ To account for background activity, a fluorescence threshold was established by viewing duplicate overlaid sections before incubation. This was subtracted from the brightness of the final digitized image to determine the fluorescence resulting from enzymatic cleavage of the substrate. Serial sections of each sample underwent a specific treatment. The effect of $\mathrm{pH}$ on enzymatic activity within healthy and diseased gingival tissues was evaluated by incubating tissue sections at $\mathrm{pH} 6.0,7.0$, or 7.8. For each $\mathrm{pH}, 3$ sections were analyzed, each under a different condition. The first section was incubated in buffer without inhibitor; the second in buffer containing a serine protease inhibitor $;^{24^{* *}}$ and the third containing ethylenediaminetetraacetic (EDTA, an MMP inhibitor). ${ }^{1 \dagger \dagger}$ These inhibitors were used to allow identification of the active proteases. Alternate sections were fixed in $4 \%$

I Molecular Probes Inc., Eugene, OR.

\# Nikon LS-2000, Nikon Inc., Melville, NY.

* * Bowman Birk Inhibitor, Sigma Chemical Co., St. Louis, MO.

$\dagger \dagger$ Sigma Chemical Co. 
formalin and stained with hematoxylin and eosin ( $\mathrm{H}$ E E) to enable a direct comparison of protease activity with tissue histology. Once digitized, the $H \& E$ stained section (Fig. 2A) was overlaid with the fluorescent image (Fig. 2B) for histologic localization and mapping of enzymatic activity. Areas of proteolysis were evident as white regions in the photomicrographs (Fig. 2C).

\section{Quantitative Analysis of Protease Activity}

The quantitation of protease activity was done using fluorescence polarization methods. Specifically, tissue extracts were prepared from the same samples that had been utilized for in situ analysis by homogenization in PBS using a polytron homogenizer. The extracts were centrifuged $\left(10,000 \times 10\right.$ minutes, $\left.4^{\circ} \mathrm{C}\right)$ and the protein concentration of the resultant supernatants was assessed with a protein assay ${ }^{\ddagger}$ using bovine serum albumin as a standard. The supernatants were aliquoted and stored at $-20^{\circ} \mathrm{C}$. For each sample, an aliquot was designated to undergo a specific treatment. Fluoresceinated substratel was used at a final concentration of $10 \mu \mathrm{g} / \mathrm{ml}$ in buffers of $\mathrm{pH} 6.0,7.0$, or 7.8 , in the presence or absence of an inhibitor: phenylmethylsulfonyl fluoride (PMSF), ${ }^{\dagger \dagger}$ a serine protease inhibitor ${ }^{25}$ $(5 \mathrm{mM})$, or $\operatorname{EDTA}^{\dagger \dagger}(20 \mathrm{mM})$. These inhibitors were included in the substrate buffers to facilitate identification of the active enzymes. Extracts were thawed, mixed with substrate, and incubated for 3 hours after which fluorescence analysis was performed with a fluorometer§§ set up at excitation/emission maxima of $595 / 615 \mathrm{~nm}$, respectively. Each extract was analyzed at 3 protein concentrations. Duplicate measurements were taken and mean fluorescence values were calculated. Results were expressed as fluorescent ratios, with the disease group set at 1 (unit).

To generate a standard reference curve, BODIPY XTlabeled casein was incubated with increasing concentrations of purified trypsin. ${ }^{\dagger \dagger}$ The resultant fluorescence was measured and expressed as absolute fluorescent values. In the region from 0 to $3 \mu \mathrm{g} / \mathrm{ml}$ of the standard reference curve, a direct correlation between fluorescence and trypsin concentration was observed (Fig. 3). This correlation was utilized to estimate the quantity of active proteases present in individual samples.

\section{Data Management and Analysis}

Each patient contributed a single tissue sample, which served as the experimental unit of analysis. The individual fluorescence value in vitro, for each of the measured parameters, was arranged by group (either healthy or inflamed), and a mean \pm SD was calculated. The null hypothesis of no difference in recorded fluorescent levels between two groups was tested for each comparison, using Student $t$ tests and Wilcoxon rank sum tests (Table 1). Sample size was established based upon an initial analysis of 3 samples from each group and designed to obtain alpha (Type I error) $<0.05$, with beta (Type II error) set at 0.20 . The results of this analysis indicated that a sample size of 6 for each group would identify a significant difference if one existed.

\section{RESULTS}

\section{In Situ Protease Activity and Histologic Mapping}

When inflamed tissue sections were evaluated at $\mathrm{pH} 7.8$, protease activity was detected predominantly within the connective tissue (Fig. 2C). This activity was inhibited in the presence of EDTA, an MMP inhibitor (Fig. 2D versus Fig. 2C). Interestingly, when tissue sections were incubated at $\mathrm{pH}$ 6.0, the enzymatic activity was localized to the epithelium (Fig. 2E). This activity was not inhibited by EDTA but was suppressed by $\mathrm{BBI}$, an inhibitor of serine proteases (Fig. $2 \mathrm{~F}$ versus $2 \mathrm{E}$ ). These results indicated that MMPs were the major form of activated proteases within the inflamed gingival tissue samples. Additionally, serine proteases were active within the epithelial compartment of these tissues at lower $\mathrm{pH}$.

Little proteolytic activity was detected within epithelia or connective tissues of healthy samples, despite the presence of inflammatory cells (Fig. 4). In contrast, maximal protease activity within the connective tissues of inflamed samples was detected at $\mathrm{pH}$ 7.8. This activity was localized to areas of intense inflammatory cell infiltration. The magnitude of connective tissue protease activity appeared to be $\mathrm{pH}$ dependent, as samples incubated at $\mathrm{pH} 6.0$ and 7.0 exhibited significantly less fluorescence when compared to sections incubated at $\mathrm{pH}$ 7.8. At the lower $\mathrm{pHs}$, increasing amounts of epithelial protease activity were detected. In contrast to healthy sections, this activity was distributed throughout the epithelia of the inflamed samples (Fig. 4).

\section{Quantitative Analysis of Protease Activity}

Incubation of healthy and inflamed tissue extracts with substrate at $\mathrm{pH} 7.8$ yielded a protease level of $0.13 \mu \mathrm{g} / \mathrm{ml}$ and $0.45 \mu \mathrm{g} / \mathrm{ml}$ trypsin equivalents, respectively. Comparison between the average protease activity contained in extracts prepared from diseased versus healthy tissues showed that diseased samples contained higher levels of proteolytic activity than controls ( 1.0 units \pm 0.05 versus 0.81 units \pm 0.02, respectively, Table 1) (Fig. 5).

PMSF, a serine protease inhibitor, reduced the enzymatic activity by $29 \%$ ( 1.0 units \pm 0.05 versus 0.82 units \pm 0.02 ). The decrease was statistically significant (Table 1, Fig. 6). The activity was significantly inhibited to an even greater extent with EDTA (75\%), a metalloprotease inhibitor ( 1.0 units \pm 0.05 versus 0.54

‡ Bio-Rad Laboratories, Hercules, CA.

$\S \S$ PTI Alphascan, Photon Technology International, South Brunswick, NJ. 


\section{A}

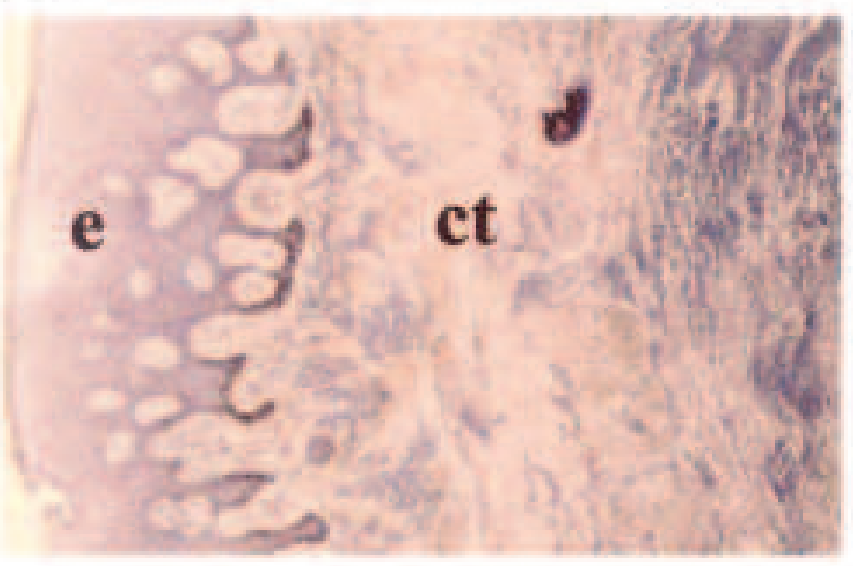

C

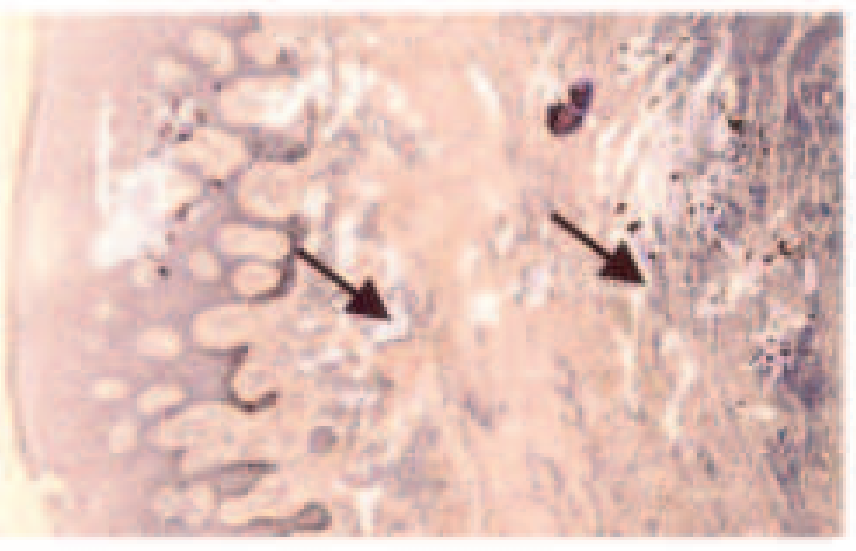

E

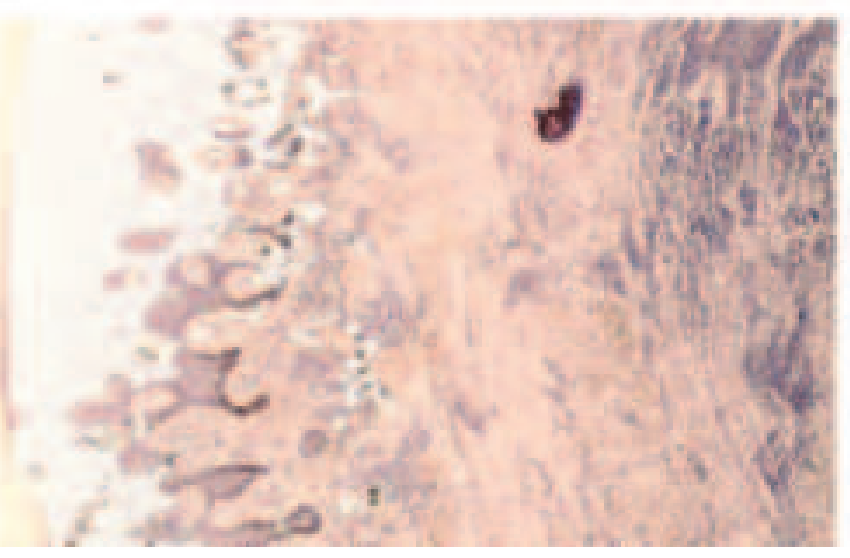

B

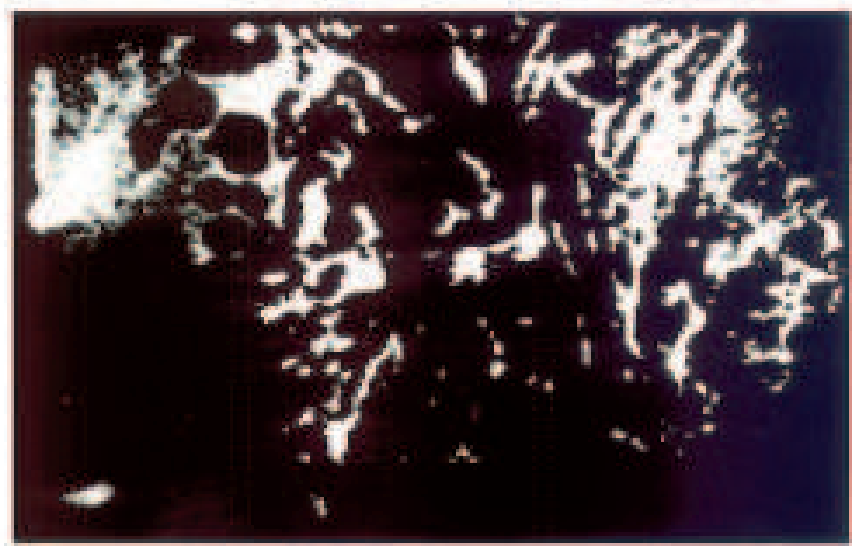

D

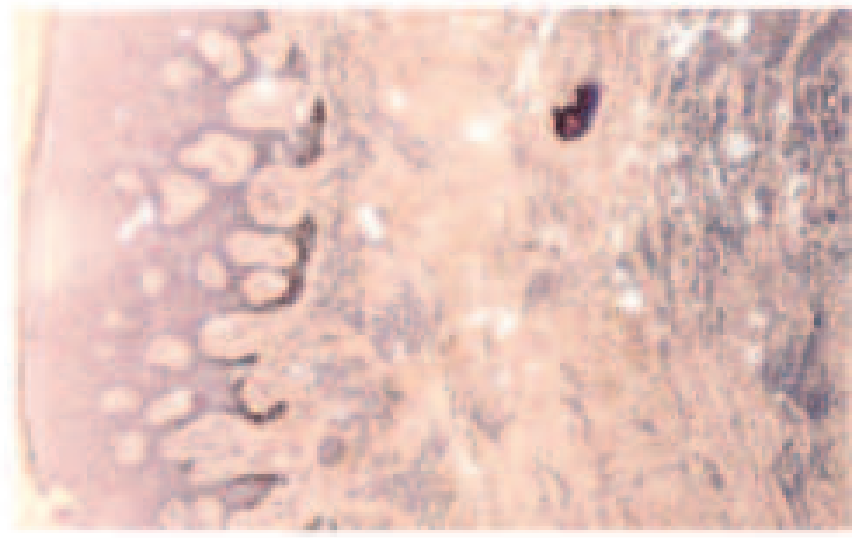

F

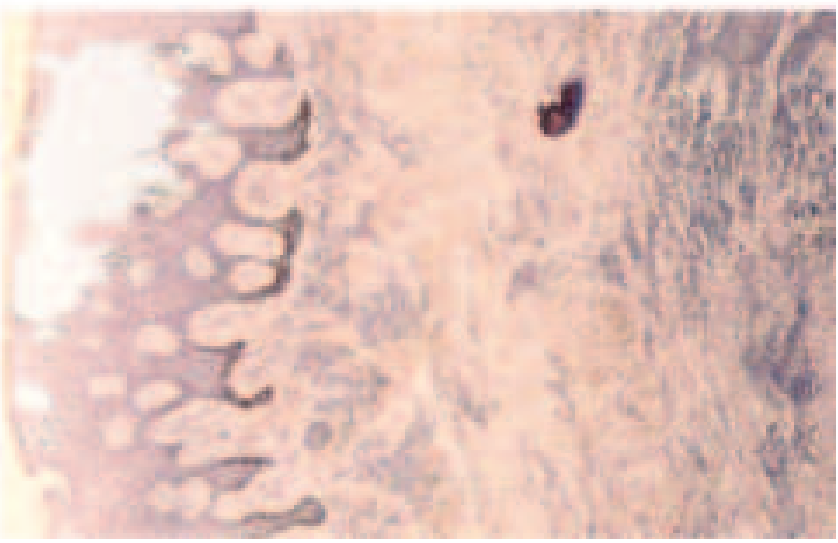

Figure 2.

Localization and characterization of protease activity in inflamed gingiva. The serial sections shown in Panels A through F were prepared from the same tissue sample. Panel $\boldsymbol{A}$ contains a transverse section stained with hematoxylin and eosin allowing identification of the gingival epithelial (e) and connective tissue (ct) compartments. Panel B is composed of a fluorescence micrograph of a serial section incubated with BODIPY TR-X labeled casein at pH 7.8. In situ proteolytic activity appears as white areas (Panels B-F). The images in Panels A and B were overlaid to generate Panel C. Protease activity is present in the connective tissue but not in the epithelium (arrows). Panel $\mathbf{D}$ demonstrates decreased protease activity in the presence of EDTA, an MMP inhibitor ( $\mathrm{pH}$ 7.8). The section shown in Panel $\mathbf{E}$ was evaluated at $\mathrm{pH} 6.0$ in the presence of EDTA and demonstrates enzymatic activity in the epithelium. Addition of BBl, a serine protease inhibitor, blocked the proteolytic activity detected within the epithelium (Panel F). 
units \pm 0.03 ; Table 1). The level of inhibition achieved by EDTA was significantly greater than that seen with PMSF $\left(p_{t \text { test }}<0.0001\right.$, $\left.p_{\text {Wilcoxon }}=0.005\right)$ (Fig. 6).

The highest level of in vitro protease activity was observed at pH 7.8 (Fig. 7). Slightly less activity was measured at $\mathrm{pH} 7.0$ ( 1.0 units \pm 0.05 versus 0.95 units $\left.\pm 0.07\left[\mathrm{p}_{t \text { test }}>0.5, \mathrm{p}_{\text {Wilcoxon }}=0.57\right]\right)$. Relative to $\mathrm{pH} 7.8$, the activity detected at $\mathrm{pH} 6.0$ was significantly decreased (1.0 units \pm 0.05 versus 0.75 units \pm $\left.0.04\left[\mathrm{p}_{t \text { test }}<0.03, \mathrm{p}_{\text {Wilcoxon }}=0.005\right]\right)$ (Fig. 7). These observations were in agreement with our findings in situ.

\section{DISCUSSION}

In the current paradigm of periodontal pathogenesis, host-derived MMPs are believed to play a major role in mediating destruction of the extracellular matrix (ECM). This is based on studies which have shown increased levels of MMPs in gingival crevicular fluid8,26-28 and extracts prepared from diseased periodontal tissues. ${ }^{5-7,9,29}$ It is established that regulation of proteolytic activity in situ is a complex phenomenon that may not be adequately replicated when evaluated by currently available in vitro assays. Therefore, the goal of the current study was 2 -fold: 1 ) to develop an assay to measure protease activity in situ and 2) to use this technology to characterize the enzymatic activity within intact gingiva. Our findings further support the concept of MMP involvement in the periodontal pathogenic process, and also indicate a potential role for serine proteases in this process.

Protease activity in situ was evaluated using a modification of the technique previously described by Galis et al. ${ }^{30}$ To our knowledge, their report is the only one addressing in situ detection of active proteases. The BODIPY TR-X-labeled $\beta$ casein substrate used for our analyses has several advantages over those used previ-

ously. Firstly, non-fluorescing substrate does not have to be washed away prior to analysis, allowing evaluation of unfixed tissue specimens. In addition, fluorescence of the substrate occurs independently of $\mathrm{pH}$ and allows for modification of buffer $\mathrm{pH}$ without impairing the fluorescence response. ${ }^{31}$ As a result, tissue sections or extracts can be examined to determine the effect of $\mathrm{pH}$ on protease activity. Finally, the red dye is

Table I.

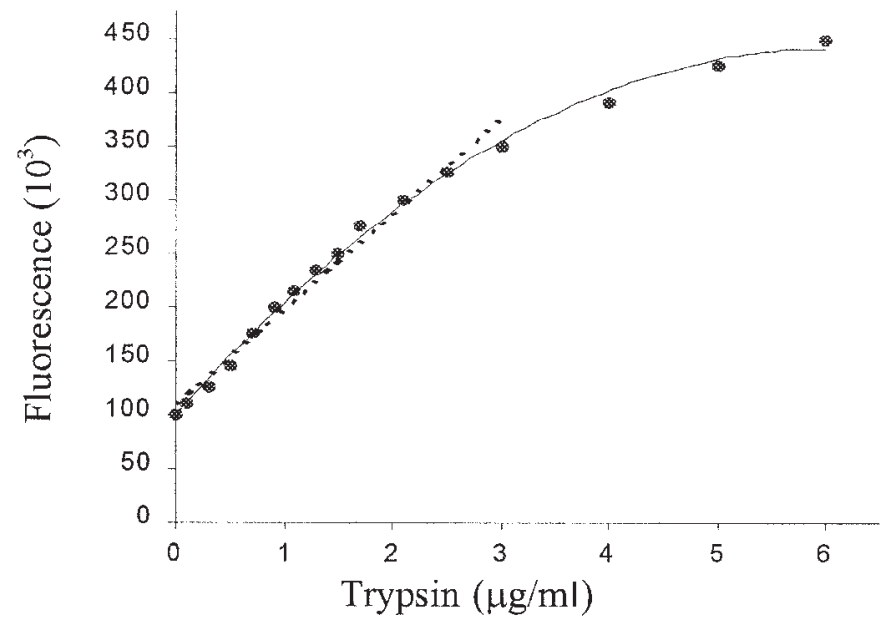

Figure 3.

Fluorescence resulting from cleavage of BODIPY TR-X labeled casein by trypsin. A standard reference curve was generated by measuring the fluorescence resulting from incubation of BODIPY TR-X labeled casein with increasing concentrations of purified trypsin $\left(3\right.$ hours at $37^{\circ} \mathrm{C}, \mathrm{pH}$ 7.8). Fluorescence was plotted as units of fluorescence $\left(\times 10^{3}\right)$. Note the sensitivity of the substrate and the linear response from 0 to 3 $\mu \mathrm{g} / \mathrm{ml}$ of trypsin $\left(r^{2}=0.98\right)$.

\section{Statistical Analysis of Protease Activity in Clinically Healthy and Diseased Tissues}

\begin{tabular}{|c|c|c|c|c|c|c|}
\hline & Mean & Median & SD & Range & $\begin{array}{c}t \text {-Test } \\
\text { (Comparison to } \\
\text { Diseased Group) }\end{array}$ & $\begin{array}{l}\text { Wilcoxon Test } \\
\text { (Comparison to } \\
\text { Diseased Group) }\end{array}$ \\
\hline Disease & 1.0 & 0.99 & 0.13 & $0.85-1.16$ & & \\
\hline Healthy & 0.81 & 0.81 & 0.04 & $0.74-0.85$ & $P<0.0$ I* & $\begin{array}{c}P=0.004^{*} \\
(z=-2.642)\end{array}$ \\
\hline Disease + PMSF & 0.82 & 0.82 & 0.05 & $0.77-0.89$ & $P<0.02^{\dagger}$ & $\begin{array}{c}P=0.01^{\dagger} \\
(z=-2.322)\end{array}$ \\
\hline Disease + EDTA & 0.54 & 0.54 & 0.07 & $0.45-0.64$ & $P<0.00007^{\ddagger}$ & $\begin{array}{l}P=0.0025^{\ddagger} \\
(z=-2.802)\end{array}$ \\
\hline
\end{tabular}

\footnotetext{
* Healthy group versus diseased group.

$\dagger$ Disease and PMSF (inhibitor of serine proteases) group versus diseased group.

₹ Disease and EDTA (inhibitor of metalloproteases) group versus diseased group.
}

visible by standard fluorescent microscopy and does not interfere with the green autofluorescence of elastin. This approach enabled us to evaluate protease activity in intact periodontal sections, where cell-cell and cellECM relationships have been maintained.

The histologic evaluation indicated that protease activity was increased in both the connective tissue and the epithelium of inflamed samples. The magni- 

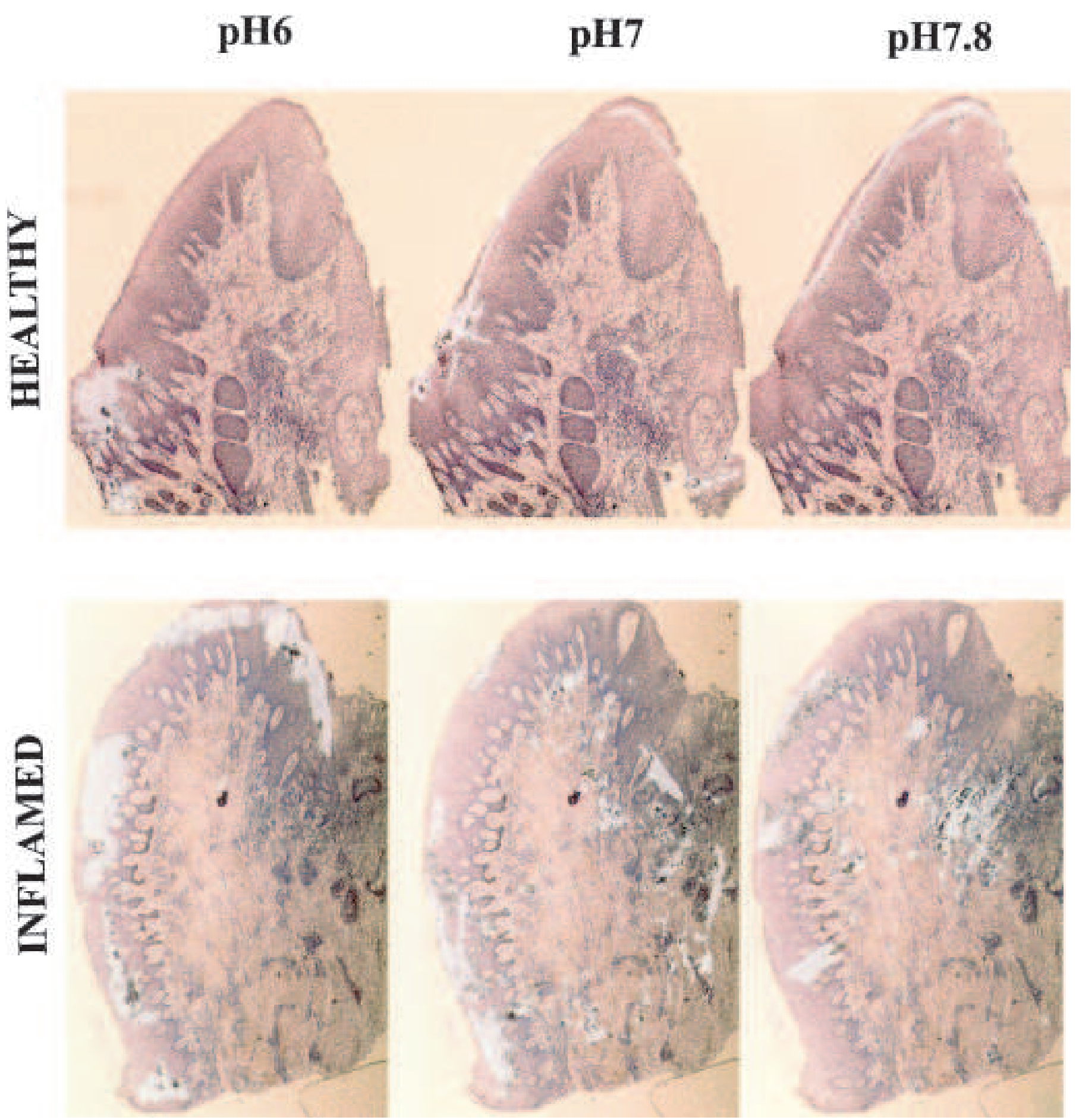

Figure 4.

The quantitative and qualitative characteristics of in situ protease activity are $\mathrm{pH}$ dependent. Serial sections prepared from clinically healthy or inflamed gingival samples were evaluated for in situ detection of protease activity (seen as white areas overlaid on $H \& E$ sections) at varying pH. In sections prepared from non-inflamed gingiva, note that protease activity was absent under all pH conditions despite the presence of inflammatory cells. In inflamed gingiva, protease activity was detected in the oral and pocket epithelia when evaluated at pH 6.0. The epithelial protease activity diminished in magnitude at pH 7.0 and 7.8. In contrast, connective tissue protease activity was maximal at pH 7.0 and 7.8. 


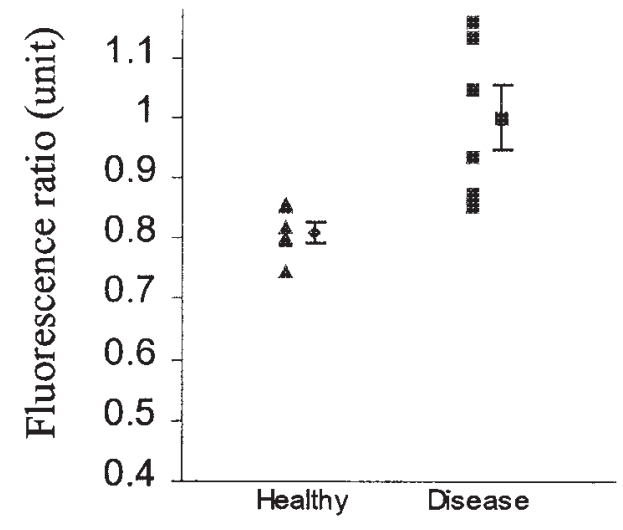

Figure 5.

Extracts prepared from healthy $(n=6)$ and inflamed $(n=6)$ gingival tissue samples were evaluated individually for protease activity. For comparison, fluorescence ratios were expressed, with the mean value of inflamed tissue samples established as a unit ( I \pm 0.05 SD). Mean activity of clinically healthy tissues was significantly decreased $(0.81 \pm$ 0.02 SD; $P<0.01$ ). Note the clustered distribution of the samples within each group.

tude of proteolytic activity within the connective tissues of these samples was highly dependent on buffer $\mathrm{pH}$. At physiologic $\mathrm{pH}$, a majority of the activity was attributable to MMPs. As would be expected, the most intense levels of protease activity were observed in the vicinity of inflammatory cells within the connective tissue subjacent to the periodontal pocket. In contrast, the epithelium of these tissues and all compartments of control samples were free of activated MMPs. These findings are consistent with those of Woolley and Davies $^{29}$ who utilized immunohistochemistry to demonstrate the presence of collagenase activity that was specifically localized to nests of inflammatory cells within the connective tissue of diseased samples. The results of our study are also compatible with those of Ingman et al. ${ }^{32,33}$ and Westerlund et al., ${ }^{34}$ who showed increased levels of MMPs $(-1,-3$, and -8$)$ and gelatinases (MMP-9 and another gelatinase [neutrophil gelatinase-associated lipocain, NGAL]) in inflamed gingival connective tissues, respectively. Taken together, these results strongly suggest that metalloproteases may play an important role in the connective tissue breakdown associated with periodontal disease.

Analysis of $H \& E$ stained sections prepared from clinically healthy control specimens allowed for identification of inflammatory cells, which can be a major source of proteases. ${ }^{35}$ Interestingly, we did not detect significant amounts of activated proteases in healthy tissue sections, despite the presence of inflammatory cells. Modest inflammatory cell infiltration of the clinically healthy periodontium is thought to represent a chronic reaction to constant bacterial challenge. ${ }^{36,37}$ In healthy tissues, the absence of activated MMPs may be

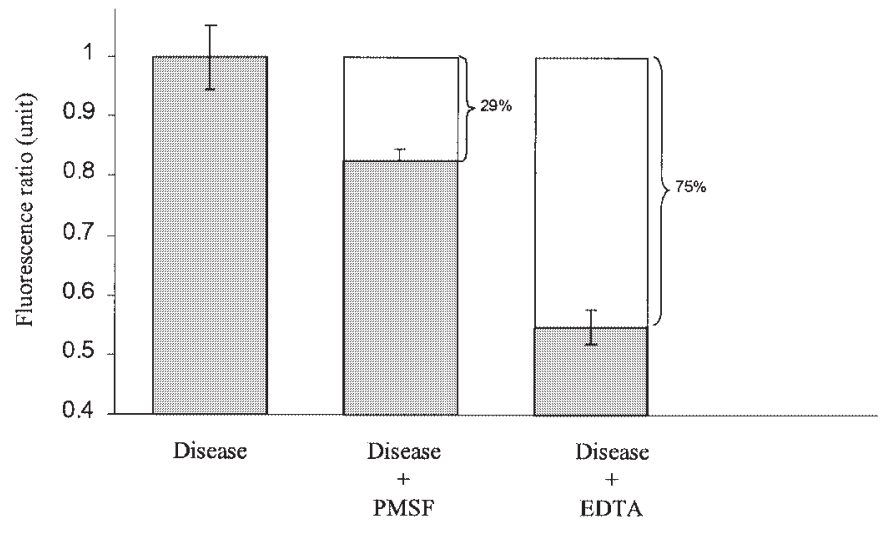

Figure 6.

MMPs were the predominant form of active proteases in extracts prepared from inflamed gingival tissues. The identification of activated proteases in tissue extracts $(n=6)$ was determined by incubating samples with BODIPY TR-X labeled casein in the presence of specific protease inhibitors $\left(3\right.$ hours at $37^{\circ} \mathrm{C}, \mathrm{pH} 7.8$ ). Fluorescence was determined and plotted as units of fluorescence $\left(\times 10^{3}\right)$. PMSF, a serine protease inhibitor, suppressed the overall activity by 29\% (1.0 units \pm 0.05 versus 0.82 units $\pm 0.02 ; P<0.02)$. EDTA, an MMP inhibitor, suppressed the activity by $75 \%$ ( 1.0 units \pm 0.05 versus 0.54 units $\pm 0.03 ; \mathrm{P}<0.00007$ ).

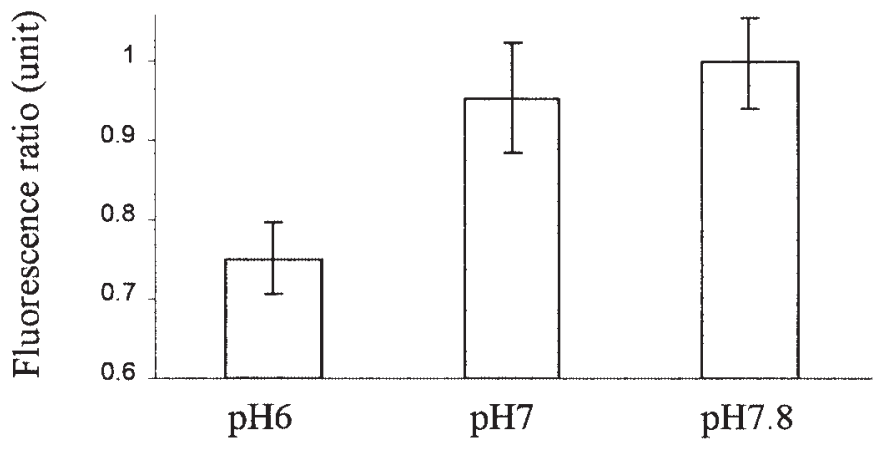

Figure 7.

The magnitude of in vitro protease activity is $\mathrm{pH}$ dependent. Extracts prepared from inflamed gingival tissues $(n=6)$ were incubated with BODIPY TR-X labeled casein at various $\mathrm{pH}\left(3\right.$ hours at $37^{\circ} \mathrm{C}$ ).

Fluorescence was determined and plotted as units of fluorescence $\left(\times 10^{3}\right)$. Maximal protease activity was observed at $\mathrm{pH}$ 7.8. There was no significant difference between the enzymatic activity measured at pH 7. 0 versus 7.8. However, when evaluated at pH 6.0, the samples exhibited significantly less protease activity ( 1.0 units \pm 0.05 versus 0.75 units $\pm 0.04 ; P<0.03$ ).

due to numerous mechanisms including: 1) cytokinemediated inhibition of protease synthesis by inflammatory cells; ${ }^{38} 2$ 2) absence of factors required for activation of latent proteases; ${ }^{13,39,40}$ and/or 3) high levels of specific MMP inhibitors (TIMPs). ${ }^{41,42}$

In addition to infiltrating inflammatory cells, resident cells within the gingiva may also serve as a source of MMPs. In vitro studies have suggested that gingival 
epithelial cells are capable of synthesizing ECMdegrading proteases. ${ }^{16,43}$ Meikle et al. ${ }^{16}$ used immunolocalization to identify collagenase in the epithelium of cultured explants. Reynolds and Hembry ${ }^{43}$ detected collagenase and stromelysin- 1 within the epithelium of cultured periodontal tissues. In the current study, we have confirmed and extended these observations by demonstrating the presence of activated serine proteases within non-manipulated inflamed gingival epithelium. Previously, serine proteases have been localized in periodontal tissues, using immunohistochemical studies. In contrast to our results, Tervahartiala et al. ${ }^{44}$ detected cathepsin G in GCF and in lamina propria beneath the sulcular epithelia only. However, cathepsin $\mathrm{G}^{45,46}$ and medullasin ${ }^{46}$ had also been found in connective tissues and pocket epithelia from periodontal patients. Our results indicate that epithelially derived active proteases reported by other groups are not an artifact of tissue culture.

The in vitro evaluation of tissue extracts via fluorometry showed significantly greater levels of protease activity in extracts prepared from diseased tissues compared to healthy control samples. By comparing the fluorescence resulting from tissue extracts to that induced by known concentrations of trypsin, we were able to estimate the quantity of enzymatic activity contained within each sample. The total concentration of active protease in extracts prepared from diseased samples was equivalent to $0.45 \mu \mathrm{g} / \mathrm{ml}$ of trypsin activity. This value is similar to the estimate of Birkedal-Hansen ${ }^{47}$ who reported the metalloprotease concentration of inflamed tissue extracts in the range of $1 \mu \mathrm{g} / \mathrm{ml}$. Although metalloproteases were the predominant form of proteolytic enzymes within inflamed samples, $29 \%$ of the total activity was due to serine proteases. Since the epithelium and connective tissues were not separated prior to preparation of tissues extracts, these values could represent the distribution of MMPs and serine proteases within the 2 tissue compartments.

Protease activity is regulated in situ at multiple levels involving transcriptional, translational, and posttranslational mechanisms. ${ }^{1,11-14}$ Since these enzymes have optimal pHs at which they are active, it is reasonable to hypothesize that tissue $\mathrm{pH}$ may serve as an additional mechanism of protease regulation. While it has been shown that gingival crevicular fluid $\mathrm{pH}$ seems to shift from acid to basic as periodontal disease progresses, ${ }^{48-50}$ little is known about the local $\mathrm{pH}$ of inflamed gingival epithelium or connective tissues, and the impact of tissue $\mathrm{pH}$ on protease activity has rarely been addressed. ${ }^{51}$ Our results demonstrated maximal connective tissue MMP activity when samples were incubated at $\mathrm{pH}$ 7.8. At lower $\mathrm{pH}$, proteolytic activity within the connective tissues diminished and the magnitude of activity seen in the epithelium increased. Furthermore, a majority of the activity seen in the epithelium appears to be attributable to serine proteases. Thus, local $\mathrm{pH}$ may affect both the quantitative and qualitative characteristics of protease activity in situ.

The aim of the current study was to extend our knowledge regarding the potential role of host-derived proteases in the pathogenesis of periodontal disease. Our results suggest that specific types of active proteases are present in different tissue compartments (i.e., epithelium and connective tissue). These findings support a role for MMPs in the degradation of inflamed gingival connective tissues, as well as a role for serine proteases, present in the gingival epithelium. The activities of these enzymes are $\mathrm{pH}$ dependent, indicating that local $\mathrm{pH}$ could represent an additional mechanism regulating protease activity in situ. Further studies are needed to clarify the mechanisms regulating protease activity in tissue and the role that these enzymes play in periodontal breakdown.

\section{ACKNOWLEDGMENTS}

The authors wish to thank Dr. Warren J. Ewens for his assistance in statistical analysis; Drs. Max A. Listgarten and Norton S. Taichman for their help with manuscript preparation; Dr. JianFei Wang for his technical assistance; and Drs. Edward T. Lally and Pamella S. Howard for their support of the project. This study was partly supported by the Dental Research Fellowship Program, Department of Veterans Affairs, Washington, DC.

\section{REFERENCES}

1. Birkedal-Hansen H. Proteolytic remodeling of extracellular matrix. Curr Opin Cell Biol 1995;7:728-735.

2. Van Der Zee E, Everts V, Beertsen W. Cytokine-induced endogenous procollagenase stored in the extracellular matrix of soft connective tissue results in a burst of collagen breakdown following its activation. J Periodont Res 1996;31:483-488.

3. Schroeder HE, Listgarten MA. The gingival tissues: The architecture of periodontal protection. Periodontol 2000 1997; 13:91-120.

4. Bennick A, Hunt AM. Collagenolytic activity in oral tissues. Arch Oral Biol 1967;12:1-9.

5. Fullmer HM, Gibson W. Collagenolytic activity in gingiva of man. Nature 1966;209:728-729.

6. Fullmer HM, Gibson AE, Lazarus GS, Bladen HA. The origin of collagenase in periodontal tissues of man. J Dent Res 1969;48:646-651.

7. Geiger S, Harper E. Human gingival collagenase in periodontal disease: The release of collagenase and the breakdown of endogenous collagen in gingival explants. J Dent Res 1980;59:11-16.

8. Golub LM, Stiegel K, Ramamurthy NS, Mandel ID. Some characteristics of collagenase activity in gingival crevicular fluid and its relationship to gingival diseases in humans. J Dent Res 1976;55:1049-1057.

9. Reynolds JJ, Hembry RM, Meikle MC. Connective tissue degradation in health and periodontal disease and the roles of matrix metalloproteinases and their natural 
inhibitors. Adv Dent Res 1994;8:312-319.

10. Aiba T, Akeno N, Kawane T, Okamoto H, Horiuchi N. Matrix metalloproteinases- 1 and -8 and TIMP-1 mRNA levels in normal and diseased human gingivae. Eur J Oral Sci 1996;104:562-571.

11. Uitto VJ, Airola K, Vaalamo M, et al. Collagenase-3 (matrix metalloproteinase-13) expression is induced in oral mucosal epithelium during chronic inflammation. Am J Pathol 1998;152:1489-1499.

12. Salo T, Lyons JG, Rahemtulla F, Birkedal-Hansen H, Larjava $\mathrm{H}$. Transforming growth factor-beta 1 upregulates type IV collagenase expression in cultured human keratinocytes. J Biol Chem 1991;266:1143611441.

13. Sorsa $T$, Ingman $T$, Suomalainen $K$, et al. Identification of proteases from periodontopathogenic bacteria as activators of latent human neutrophil and fibroblast-type interstitial collagenases. Infect Immun 1992;60:4491 4495.

14. Owen CA, Campbell EJ. Neutrophil proteinases and matrix degradation. The cell biology of pericellular proteolysis. Semin Cell Biol 1995;6:367-376.

15. Cooksley S, Hipkiss JB, Tickle SP, et al. Immunoassays for the detection of human collagenase, stromelysin, tissue inhibitor of metalloproteinases (TIMP) and enzyme-inhibitor complexes. Matrix 1990; 10:285-291.

16. Meikle MC, Hembry RM, Holley J, Horton C, McFarlane CG, Reynolds JJ. Immunolocalization of matrix metalloproteinases and TIMP-1 (tissue inhibitor of metalloproteinases) in human gingival tissues from periodontitis patients. J Periodont Res 1994;29: 118-126.

17. Harris ED, Vater CA. Methodology of collagenase research: Substrate preparation, enzyme activation and purification. In: Woolley DE, Evanson JM, eds. Collagenase in Normal and Pathological Connective Tissues. New York: John Wiley and Sons Ltd.; 1980:3.

18. Meitner S, Zander H, Iker H, Polson A. Identification of inflamed gingival surfaces. J Clin Periodontol 1979;6: 93-100.

19. Polson AM, Garrett S, Stoller NH, et al. Multicenter comparative evaluation of subgingivally delivered sanguinarine and doxycycline in the treatment of periodontitis. I. Study design, procedures and managements. J Periodontol 1997;68:110-118.

20. Nyman S, Lindhe J. Examination of patients with periodontal disease. In: Lindhe J, ed. Clinical Periodontology and Implant Dentistry, 3rd ed. Copenhagen: Munksgaard; 1997:383-395.

21. Polson AM, Caton JG, Yeaple RN, Zander AH. Histological determination of probe tip penetration into the gingival sulcus of humans using an electronic pressuresensitive probe. J Clin Periodontol 1980;7:479-488.

22. Greenstein G, Caton J, Polson AM. Histologic characteristics associated with bleeding after probing and visual signs of inflammation. J Periodontol 1981;52: 420-525.

23. Haugland RP. Detecting peptidases and proteases. In: Spence MTZ, ed. Handbook of Fluorescent Probes and Research Chemicals, 6th ed. Eugene, OR: Molecular Probes; 1996:230-232.

24. Birk Y. The Bowman Birk Inhibitor. Int $J$ Peptide Protein Res 1985;25:113-131.

25. Laura R, Robison DJ, Bing DH. (p-Amidinophenly) methanesulfonyl fluoride, an irreversible inhibitor of serine proteases. Biochemist 1980;19:4859-4864.
26. Haerian A, Adonogianaki E, Mooney J, Docherty JP, Kinane DF. Gingival crevicular stromelysin, collagenase and tissue inhibitor of metalloproteinase levels in healthy and diseased sites. J Clin Periodontol 1995;22:505-509.

27. Larivee L, Sodek J, Ferrier JM. Collagenase and collagenase inhibitor activities in crevicular fluid of patients receiving treatment for localized juvenile periodontitis. J Periodont Res 1986;21:702-715.

28. Eley BM, Cox SW. Cathepsin B/L, elastase-, tryptase-, trypsin, and dipeptidyl peptidase IV-like activities in gingival crevicular fluid: Correlation with clinical parameters in untreated chronic periodontitis patients. J Periodont Res 1992;27:62-69.

29. Woolley DE, Davies RM. Immunolocalization of collagenase in periodontal disease. J Periodont Res 1981;16:287-297.

30. Galis ZS, Sukhova GK, Libby P. Microscopic localization of active proteases by in situ zymography: Detection of matrix metalloproteinase activity in vascular tissue. FASEB J 1995;9:974-980.

31. Jones LJ, Upson RH, Haugland RP, et al. Quenched BODIPY Dye-labeled casein substrates for the assay of protease activity by direct fluorescence measurement. Anal Biochem 1997;251:144-152.

32. Ingman T, Sorsa T, Michaelis J, Konttinen YT. Immunohistochemical study of neutrophil- and fibroblast-type collagenases and stromelysin-1 in adult periodontitis. Scand J Dent Res 1994;102:342-349.

33. Ingman T, Sorsa T, Michaelis J, Konttinen YT. Matrix metalloproteinases-1,3,8 in adult periodontitis in situ. Ann NY Acad Sci 1994;732:459-461.

34. Westerlund U, Ingman T, Lukinmaa PL, et al. Human neutrophil gelatinase and associated lipocalin in adult and localized juvenile periodontitis. J Dent Res 1996;75: 1553-1563.

35. Etherington DJ, Pugh D, Silver IA. Collagen degradation in an experimental inflammatory lesion: Studies on the role of the macrophage. Acta Biol Med Ger 1981;40: 1625-1636.

36. Page RC, Schroeder HE. Pathogenesis of inflammatory periodontal disease. A summary of current work. Lab Invest 1976;33:235-249.

37. Kinane DF, Lindhe J. Pathogenesis of periodontitis. In: Lindhe J, ed. Clinical Periodontology and Implant Dentistry, 3rd ed. Copenhagen: Munksgaard; 1997: 194-195.

38. Gross J, Highberger JH, Jonhson-Wint B, Biswas C. Mode of action and regulation of tissue collagenases. In: Woolley DE, Evanson JM, eds. Collagenases in Normal and Pathological Connective Tissues. New York: J. Wiley and Sons Ltd; 1980.

39. Van Der Zee E, Everts V, Beertsen W. Cytokine-induced endogenous procollagenase stored in the extracellular matrix of soft connective tissue results in a burst of collagen breakdown following its activation. J Periodont Res 1996;31:483-488.

40. DeCarlo AA, Windsor LJ, Bodden MK, Harber GJ, Birkedal-Hansen B, Birkedal-Hansen H. Activation and novel processing of matrix metalloproteinases by a thiolproteinase from the oral anaerobe Porphyromonas gingivalis. J Dent Res 1997;76:1260-1270.

41. Nomura T, Takahashi T, Hara K. Expression of TIMP-1, TIMP-2 and collagenase mRNA in periodontitis-affected human gingival tissue. J Periodont Res 1993;28: 354-362.

42. Woessner JF. Matrix metalloproteinases and their inhibitors in connective tissue remodeling. FASEB 
$J$ 1991;5:2145-2154.

43. Reynolds JJ, Hembry RM. Immunolocalization of metalloproteinases and TIMP in normal and pathological tissues. Matrix Suppl 1992;1:375-385.

44. Tervahartiala T, Konttinen YT, Ingman T, HayrinenImmonen R, Ding Y, Sorsa T. Cathepsin G in gingival tissue and crevicular fluid in adult periodontitis. J Clin Periodontol 1996;23:68-75.

45. Kennett CN, Cox SW, Eley BM. Comparative histochemical, biochemical and immunohistochemical studies of cathepsin B in human gingiva. J Periodont Res 1994;29:203-213.

46. Kunimatsu K, Ozaki Y, Hara Y, Aoki Y, Yamamoto K, Kato I. Immunohistochemical study of cathepsin G and medullasin in inflamed gingival tissues from periodontal patients. J Periodont Res 1997;32:264-270.

47. Birkedal-Hansen H. Role of matrix metalloproteinases in human periodontal diseases. J Periodontol 1993;64: 474-484.

48. Kleinberg I, Hall G. pH and depth of gingival crevices in different areas of the mouth of fasting humans. J Periodont Res 1968;3:109-117.

49. Bicket $M$, Cimasoni G. The $\mathrm{pH}$ of human crevicular fluid measured by a new microanalytical technique. $J$ Periodont Res 1985;20:35-40.

50. Leblebicioglu B, Lim JS, Cario AC, Beck MF, Walters JD. $\mathrm{pH}$ changes observed in the inflamed gingival crevice modulate human polymorphonuclear leukocyte activation in vitro. $J$ Periodontol 1996;67:472-477.
51. Korostoff JM, Wang JF, Sarment DP, Feldman R, Billings PC. Increased levels of activated gelatinase A (MMP-2) and serine proteases in chronic adult periodontitis. $J$ Periodontol; in press.

Send reprint requests to: Dr. David P. Sarment, Department of Periodontics/Prevention/Geriatrics, University of Michigan School of Dentistry, 1011 N. University Ave., Ann Arbor, MI 48109-1078. Fax: 734/763-5503; e-mail: sarment@ umich.edu

Accepted for publication April 13, 1999. 